$\begin{array}{ll}\text { Variants } & \begin{array}{l}\text { Variants } \\ \text { The Journal of the European Society for Textual } \\ \text { Scholarship }\end{array}\end{array}$

15-16 | 2021

Textual Scholarship in the Twenty-First Century

\title{
From Christ the Saviour to God the Father:
}

Adjustments

to Forgiveness in Donne's Short Poem, "Wilt thou forgive...'

Anthony Lappin

\section{(2) OpenEdition \\ Journals}

Electronic version

URL: https://journals.openedition.org/variants/1330

DOI: $10.4000 /$ variants. 1330

ISSN: 1879-6095

Publisher

European Society for Textual Scholarship

Printed version

Date of publication: 1 July 2021

Number of pages: 123-154

ISSN: 1573-3084

Electronic reference

Anthony Lappin, "From Christ the Saviour to God the Father: Adjustments

to Forgiveness in Donne's Short Poem, "Wilt thou forgive. . ." ", Variants [Online], 15-16 | 2021, Online since 01 July 2021, connection on 16 July 2021. URL: http://journals.openedition.org/variants/1330 * DOI: https://doi.org/10.4000/variants.1330

This text was automatically generated on 16 July 2021.

The authors 


\title{
From Christ the Saviour to God the Father: Adjustments to Forgiveness in Donne's Short Poem, "Wilt thou forgive..."
}

\author{
Anthony Lappin
}

\section{Introduction}

1 JOHN DONNE (1572-1631) TRAINED AS A LAWYER, and made something of a name for himself as a coterie poet through well-turned erotic and satyrical verse (Mariotti 1986). He had renounced his familial allegiance to Catholicism following his recusant brother's death in prison, and looked set on a diplomatic career, beginning first in the service of Lord Egerton, keeper of the king's seal. Yet Donne's secret marriage in 1601 to a teenage heiress, Anne More, destroyed his prospects, resulted in her disinheritance, and plunged them into poverty; Anne died during her twelfth lying-in in the summer of 1617. Despite having shown little interest in religious matters other than as antiCatholic polemicist, Donne had been forced into the clergy two years earlier and had taken up the only means of preferment then open to him, as one of the royal chaplains, at the insistence of James VI and I (1566-1625), who, one must assume, thought he had more than enough lawyers but a dearth of entertaining clergymen.

Donne's early secular poetic expression and his later assumption of a religious garb he was made dean of St Paul's in 1621 and became something of a superstar preacher has caused a certain degree of difficulty for editors, readers and, as we shall see, copyists. In this article, then, I shall consider how assumptions regarding the manner in which religious verse should express itself, and how in particular the dean of St Paul's should have expressed himself, influenced the transmission of one particular poem which, quite self-consciously, escaped from the norms of devotional poetry. Donne preferred most of his writing - and particularly his poetry - to circulate in 
manuscript. This, of course, granted a degree of control over whom it might reach, and in what form it might reach them. Yet it also allowed a certain variance to creep in to the transmission of the poems, through scribal variants or errors, and scribal rewritings or recomposition. Such interference on the part of a scribe might remain independent of other variant versions, or might, in contrast, be designed to resonate with or correct other incarnations of the poem.

3 A perfectly licit engagement with textual variance is to inquire after what text (be that hypothetical, arrived at by deducation, or real, present in a surviving manuscript) might be closest to the original version - the one, so to speak, issued by the poet, and therefore the one most fully expressing their intentions; and, as a corollary of this activity, to establish whether any variants found in the manuscript tradition might come from a revision by the author of their original text. Of course, if this is one's focus, anything extra-authorial, or even authorial elements that are revised away, should be set aside, as good for little other than to fill an apparatus whose presence is as inexplicable as its contents are unread. In this article, however, I shall use the numerous variants to discuss the evolution of a poem in copyists' hands, and focus on the variant understandings of a poem - variant instantiations of a poem - which were generated in different, yet still roughly contemporary, contexts. The poem in question has been usually referred to as "A Hymne to God the Father", following the title provided in the first edition of Donne's poetry, which came to be inscribed in the Stationers' Register a year and a half after his death as "a booke of verses and Poems [...] written by Doctor John Dunn" (13 September 1632: Arber (1877, IV:249)). It was published some six months later; the "Hymne" appeared as the final poem of Donne's oeuvre (Donne 1633, 350). The poem maintained this position, as the final poem of the final section - that of religious verse - in the revised second edition (Donne 1635, 350), and all subsequent seventeenth-century editions $(1639,388 ; 1649,1650,1654,368)$. It was this printed text which, with some small alterations, passed over into Izaac Walton's Life of Donne, and so became very much the textus receptus for those who wished to sample the poetic lyre of the Anglican divine, as Walton was pleased to present him (see Martin (2003); Novarr (1958); Smith (1983, 116-17); further, Lambert (2012); Cottegnies (1999); Haskin (2007, 11-13)).

By the twentieth century, though, some comparison with the variant readings present in manuscripts had taken place, and the textus receptus gave way to editorial conflations of disparate readings (see Pebworth 1987, nn. 6-7, at 26-27). This eclecticism has been eschewed by the poem's most recent editor, Robin Robbins (2013, 654-56), who adopts the text as found in Trinity College Dublin, ms. 877, fol. 135r [DT1], ${ }^{1}$ an election justified by the observation that the manuscript represents the only witness "free of inferior readings". As an ecdotic definition, it is rather wanting, and a side effect of the first part of the present article will be a partial contribution to evaluating this form of editorial connoisseurship.

5 The article will develop in the following stages: I shall consider previous discussion of the poem's textual evolution. I shall then progress to widen my interrogation of the transmission by using variants not previously considered, and will use this variation to reconstruct a hypothetical stemma for the poem. The purpose of this is not solely to identify those copies as close to the archetype as possible, but also to gain a comprehensive vision of the overall variance of the poem at the hands of scribes and printers. This overview will then be used to provide a literary analysis of the poem and 
its variants. I will attempt to reconstruct how the poem has been re-interpreted consistently through its copying history, in relation to various cultural forces.

\section{The First Moments of Evolution: Pebworth 1987}

Over three decades ago, Ted-Larry Pebworth provided a subtle analysis of the development of the text, tracing its evolution via three significant stages. "Text 1", in his view the earliest, corresponded to the well-established sub-set of Donne manuscripts, known as Group III; "Text 2" to manuscript Group II; and "Text 3" to the printed text of 1633. Although I will argue that the manuscript transmission of this poem is much more complex than Pebworth's analysis allows, and that variants in other witnesses should be taken much more seriously, it is important to emphasize the careful work that Pebworth carried out and upon which depends my own unpicking of an inevitably only partially-preserved web of transmission.

\section{Text 1}

Pebworth's identification of the stages of transmission are distinguished by, amongst other things, their titles. "Christo Saluatori" [To Christ the Saviour] is the title born by, in Pebworth's careful words, "a fairly accurate verbal record of the earliest version of the poem" $(1987,23)$, and is represented by four manuscripts, two dating to the 1620 s:

\begin{tabular}{|l|l|}
\hline B29 & London, British Library, Harleian ms. 3910, fol. 50r \\
\hline B46 & London, British Library, Stowe ms. 961, fol. 109r \\
\hline
\end{tabular}

and two to the early 1630s:

\begin{tabular}{|l|l|}
\hline H6 & Harvard ms. Eng. 966.5, fol. 15v \\
\hline C10 & Cambridge, University Library, Narcissus Luttrell ms., fol. 93v. \\
\hline
\end{tabular}

\section{Text 2}

9 The second, entitled "To Christ", is described as a "grammatical and aesthetic "tidying up' by either the poet or a copyist" (1987, 21 and 23). The attribution is regrettably imprecise, but Pebworth certainly intended to leave open the possibility that Donne returned to his poem, and carried out a number of changes to improve it.

The manuscripts concerned are, in the main, from the mid-1620s:

\begin{tabular}{|l|l|}
\hline B7 & London, British Library, Add. ms. 18647, fol. 91v \\
\hline CT1 & Cambridge, Trinity College Cambridge, ms R. 3.12, p. 200 \\
\hline
\end{tabular}




\begin{tabular}{|l|l|}
\hline DT1 & Trinity College Dublin ms. 877, fol. 135r \\
\hline H4 & Harvard ms. Eng. 966.3, fol. 113r \\
\hline H5 & Harvard ms. Eng 966.4, fol. 94v \\
\hline
\end{tabular}

11 Nevertheless, even with the evidence that Pebworth marshalls, we must observe that the process by which "Text 2" was reached took place in two or three moments: a change in title to the vernacular, but maintenance of the readings of the earlier "Text 1 " in just one manuscript, $\mathrm{H} 5$, which was then followed by a number of significant changes in the subsequent manuscripts (H4, DT1; B7, CT1).

We may thus present a representation of something close to the original text together with variants brought about through the progressive evolution of the poem: I have adopted a modernized spelling to avoid insignificant orthographical variation. ${ }^{2}$ Superscript words indicate the later variants of the underlined words preceding them.

\section{A combined edition of the text}

Christo Salutori...

\section{Christo Saluatori $^{\text {To Christ }}$}

Wilt thou forgive that sin where I begun? Which is my sin though it was ${ }^{\text {were }}$ done before, Wilt thou forgiue those sins through which I run And do them still, though still I do deplore When thou hast done, I have ${ }^{\text {thou hast }}$ not done, 5 For I have more.

Wilt thou forgiue that $\sin$ by which $\underline{I}^{\text {I have }}$ won Others to sinn and made my sinn their dore Wilt thou forgiue that sinn which I did shun A year to two, but wallowed in a score

When thou hast done done that , thou hast not done for I have more.

I have a sin of feare that when I haue spun My last thred I shall perish on the shore Sweare by thy selfe that at my death thy ${ }^{\text {this }}$ sun shall shine as it shines now as heretofore And having done that, thou hast done I have no more.

The transmission may be presented in tabular form (Table 1).

Table 1: List of variant readings, Texts 1-2

\begin{tabular}{|l|l|l|l|l|}
\hline line & mss. & reading & variant & mss. \\
\hline
\end{tabular}




\begin{tabular}{|l|l|l|l|l|}
\hline Tit. & B29 B46 H6 C10 & Christo salvatori & To Christ & H5 H4 DT1 B7 CT1 \\
\hline 2 & B29 B46 H6 C10 H5 & was & were & H4 DT1 B7 CT1 \\
\hline 5 & B29 B46 H6 C10 H5 & I have & thou hast & H4 DT1 B7 CT1 \\
\hline 7 & B29 B46 H6 C10 H5 & I & I have & H4 DT1 B7 CT1 \\
\hline 11 & B29 B46 H6 C10 H5 H4 DT1 & done & done that & B7 CT1 \\
\hline 15 & B29 B46 H6 C10 H5 & thy & this & H4 DT1 B7 CT1 \\
\hline st. II-III & B29 B46 H6 C10 H5 H4 DT1 & II-III & III-II & B7 CT1 \\
\hline subscr. & B29 B46 H4 DT1 & finis & om. & H6 C10 H5 B7 CT1 \\
\hline
\end{tabular}

14 The course of transmission, and the relations of the witnesses, is relatively evident, with the only uncertainty being generated by the single-word subscription or colophon, "finis". The subscription is present in both B29 and B46; yet, from the same "Christo salvatori" group, it is missing from $\mathrm{H} 6$ and C10. Regrettably, it is not possible to say therefore whether it was contained in the archetype. Any conclusion would be wholly tentative, since we should allow for a degree of scribal latitude in choosing or not to omit something which is not part of the poem proper, but simply a boundarymarker to indicate that the poem had, in fact, already finished. We have something of a Schrödinger's archetype, then, which requires some further determination we have not yet achieved (an autograph, further evidence for Donne's own subscriptions for poems, for example). Finis is dropped by the first representative of "To Christ", H6, but it is preserved by H4 and DT1. Thus we may say with confidence that the intermediary subarchetype which changed the title still kept finis, and it was spontaneously voided by the scribe of H6. This may be transformed into a sequence of emendations:

Sequence of variation, Texts 1-2

\begin{tabular}{|l|l|l|l|l|}
\hline stage & definition & witnesses & variant & $\begin{array}{l}\text { further } \\
\text { development }\end{array}$ \\
\hline X & text of the archetype & B29 B46 & & \\
\hline 00 & & H6 C10 & om. finis / add. finis B29 B46 & \\
\hline 01 & change of title & H5 & To Christ & om. finis \\
\hline 02 & $\begin{array}{l}\text { variants to ll. 2, 5, 7, } \\
\text { H4 DT1 B7 }\end{array}$ & $\begin{array}{l}\text { Were; add. hast; add. have; } \\
\text { this }\end{array}$ & \\
\hline 03 & 1.11, order of stanzas & B7 CT1 & add. that; transp. st. II-III & om. finis \\
\hline
\end{tabular}




\section{The Poem in Flux}

Given this result, it would be better to speak provisionally of a succession of stages in transmission, rather than Pebworth's "Text 1" and "Text 2". These stages may be further refined by taking in a larger spread of manuscripts and the first printed version. Some of these witnesses Pebworth dismissed as being "memorial constructs", as they were present in commonplace books or multiple-author collections and they escaped from the much tidier pattern he had established. These witnesses are:

\begin{tabular}{|l|l|}
\hline B24 & British Library, Egerton ms. 2013 [B24], fol. 13v, the setting of the poem by John Hilton \\
\hline B47 & $\begin{array}{l}\text { London, British Library, Stowe ms. 962, fol. 220r-v, an anthology of poetry from various } \\
\text { authors }\end{array}$ \\
\hline H9 & $\begin{array}{l}\text { Harvard, ms. Eng. 1107, folder 15, a copy by Thomas Gell (1595-1667), who was both an MP } \\
\text { and member of the Inner Temple, on a single folio leaf }\end{array}$ \\
\hline HH6 & $\begin{array}{l}\text { San Marino CA, The Huntingdon Library, ms. HM 41456, fol. 183v, an anthology volume } \\
\text { containing only this work from Donne's oeuvre }\end{array}$ \\
\hline O3 & Oxford, Bodleian Library, Ashmole ms. 38, p. 14; like B47, a multiple-author florilegium \\
\hline 1633 & $\begin{array}{l}\text { Poems, by J. D. With Elegies on the Authors Death. London: M[iles] F[lesher] for Iohn Marriot, p. } \\
350\end{array}$ \\
\hline
\end{tabular}

16 A full list of variant readings drawn from all witnesses is given in Table 3; references are to the line (e.g. 14), and then (if necessary) the subsequent variants within that line (e.g. 14.ii), and finally the sequence of variants to that point in the text (e.g. 14.ii.b). The manuscripts are ordered according to their presence in the stemma, which is established below, in Table 4, and shown in Figure 1 Where witnesses contain a unexpected variant, according to their overall allegiances within the stemma, this is indicated in italics and commented on subsequently in discussion of the subarchetypes.

Table 3: List of variant readings

\begin{tabular}{|l|l|l|l|l|}
\hline line & mss. & reading & variant & mss. \\
\hline & & & & \\
\hline line & mss. & reading & variant & mss. \\
\hline Tit.a & B29 D46 H6 C10 & $\begin{array}{l}\text { Christo } \\
\text { salvatori }\end{array}$ & To Christ & $\begin{array}{l}\text { H5 H9 03 H4 DT1 } \\
\text { B7 CT1 }\end{array}$ \\
\hline Tit.b & & & om. & B47 B24 \\
\hline Tit.c & & & To God Æternall & HH6 \\
\hline
\end{tabular}




\begin{tabular}{|c|c|c|c|c|}
\hline Tit.d & & & $\begin{array}{l}\text { A Hymn to God the } \\
\text { Father: }\end{array}$ & 1633 \\
\hline 1.a & $\begin{array}{l}\text { В29 В46 H6 C10 H5 HH6 } \\
1633 \text { H4 DT1 B7 CT1 }\end{array}$ & that $\sin$ & the $\sin$ & H9 B47 \\
\hline 1.b & & & the sins & B24 \\
\hline 1.c & & & those sins & 03 \\
\hline $2 . \mathrm{i}$ & $\begin{array}{l}\text { В29 B46 H6 C10 H5 B47 } \\
\text { В24 HH6 H4 DT1 B7 CT1 }\end{array}$ & is my $\sin$ & was my sin & H9 O3 1633 \\
\hline 2.ii & $\begin{array}{l}\text { B29 B46 H6 C10 H5 H9 O3 } \\
\text { B47 }\end{array}$ & was & were & $\begin{array}{l}\text { B24 HH6 } 1633 \text { H4 } \\
\text { DT1 B7 CT1 }\end{array}$ \\
\hline 3.a & $\begin{array}{l}\text { В29 В46 H6 C10 H5 H9 O3 } \\
\text { В24 HH6 H4 DT1 В7 CT1 }\end{array}$ & those sins & the sins & B47 \\
\hline $3 . b$ & & & that $\sin$ & 1633 \\
\hline $4 . \mathrm{a}$ & $\begin{array}{l}\text { B29 B46 H6 C10 H5 H9 O3 } \\
\text { B47 B24 HH6 H4 DT1 B7 } \\
\text { CT1 }\end{array}$ & them & run & 1633 \\
\hline $4 . \mathrm{b}$ & $\begin{array}{l}\text { B29 B46 H6 C10 H5 H9 O3 } \\
\text { B24 HH6 } 1633 \text { H4 DT1 B7 } \\
\text { CT1 }\end{array}$ & I do & I them & B47 \\
\hline $5 . \mathrm{i}$ & $\begin{array}{l}\text { B29 B46 H6 C10 H5 H9 B24 } \\
\text { HH6 } 1633 \text { H4 DT1 B7 CT1 }\end{array}$ & thou hast done & this is done & O3 B47 \\
\hline 5.ii & В29 B 46 H6 C10 H5 & I have & thou hast & $\begin{array}{llll}\text { H9 O3 } & \text { B47 } & \text { B24 } & \text { HH6 } \\
1633 & \text { H4 } & \text { DT1 } & \text { B7 } \\
\text { CT1 } & & & \end{array}$ \\
\hline 7.i.a & $\begin{array}{l}\text { B29 B46 H6 C10 H5 H9 B24 } \\
\text { H4 DT1 B7 CT1 }\end{array}$ & that $\sin$ by & the $\sin$ by & B47 \\
\hline 7.i.b & & & those sins with & 03 \\
\hline 7.i.c & & & the $\sin$ (om. of) & HH6 \\
\hline 7.i.d & & & that $\sin$ (om. of) & 1633 \\
\hline 7.ii & $\begin{array}{l}\text { B29 B46 H6 C10 H5 H9 O3 } \\
\text { B47 B24 }\end{array}$ & I won & I have won & $\begin{array}{l}\text { HH6 } 1633 \text { H4 DT1 } \\
\text { B7 CT1 }\end{array}$ \\
\hline 8.a & $\begin{array}{l}\text { B29 B46 H6 C10 H5 B47 } \\
\text { B24 HH6 } 1633 \text { H4 DT1 B7 } \\
\text { CT1 }\end{array}$ & $\begin{array}{l}\text { made my sin } \\
\text { their }\end{array}$ & made their sin my & 03 \\
\hline $8 b$ & & & their $\sin ^{\text {was }} \mathrm{my}$ & H9 \\
\hline
\end{tabular}




\begin{tabular}{|c|c|c|c|c|}
\hline $9 a$ & $\begin{array}{l}\text { B29 B46 H6 C10 H5 H9 B24 } \\
\text { HH6 } 1633 \text { H4 DT1 B7 CT1 }\end{array}$ & that sin & the $\sin$ & B47 \\
\hline $9 b$ & & & these sins & 03 \\
\hline 11.i & $\begin{array}{l}\text { В29 B46 H6 C10 H5 H9 B24 } \\
\text { HH6 } 1633 \text { H4 DT1 B7 CT1 }\end{array}$ & thou hast & this is & O3 B47 \\
\hline 11.ii & $\begin{array}{l}\text { B29 B46 H6 C10 H5 H9 O3 } \\
\text { B47 B24 HH6 } 1633 \text { H4 DT1 }\end{array}$ & done & done that & B7 CT1 \\
\hline 12 & $\begin{array}{l}\text { B29 D46 H6 C10 H9 B24 } \\
\text { HH6 } 1633 \text { H5 H4 DT1 B7 } \\
\text { CT1 }\end{array}$ & thou hast & I have & H9 O3 B47 \\
\hline 13.i & $\begin{array}{l}\text { B29 D46 H6 C10 H5 B24 } \\
\text { HH6 } 1633 \text { H4 DT1 B7 CT1 }\end{array}$ & that & least & H9 O3 B47 \\
\hline 13.ii & $\begin{array}{l}\text { B29 D46 H6 C10 H9 B24 } \\
\text { HH6 } 1633 \text { H5 H4 DT1 B7 } \\
\text { CT1 }\end{array}$ & when I have & having & O3 B47 \\
\hline $14 . \mathrm{i}$ & $\begin{array}{l}\text { B29 B46 H6 C10 H5 H9 B47 } \\
\text { B24 HH6 } 1633 \text { H4 DT1 B7 } \\
\text { CT1 }\end{array}$ & my last thread & om. last & 03 \\
\hline 14.ii.a & $\begin{array}{l}\text { В29 В46 H6 C10 H5 B24 } \\
\text { HH6 } 1633 \text { H4 DT1 B7 CT1 }\end{array}$ & shall & should & H9 B47 \\
\hline 14.ii.b & & & om. & 03 \\
\hline 14.iii & $\begin{array}{l}\text { B29 B46 H6 C10 H5 H9 B47 } \\
\text { B24 HH6 } 1633 \text { H4 DT1 B7 } \\
\text { CT1 }\end{array}$ & the & this & 03 \\
\hline $15 . \mathrm{i}$ & $\begin{array}{l}\text { B29 B46 H6 C10 H5 H9 O3 } \\
\text { B47 B24 HH6 H4 DT1 B7 } \\
\text { CT1 }\end{array}$ & Swear & But swear & 1633 \\
\hline 15.ii.a & $\begin{array}{l}\text { В29 B46 H6 C10 H5 B47 } \\
\text { В24 HH6 } 1633\end{array}$ & thy sun & this sun & O3 H4 DT1 B7 CT1 \\
\hline 15.ii.b & & & the sun & H9 \\
\hline 16.i.a & $\begin{array}{l}\text { B29 B46 H6 C10 H5 H9 O3 } \\
\text { HH6 H4 DT1 B7 CT1 }\end{array}$ & as it & as he & B24 1633 \\
\hline 16.i.b & & & on me & B47 \\
\hline 16.ii.a & $\begin{array}{l}\text { B29 B46 H6 C10 H5 H4 DT1 } \\
\text { B7 CT1 }\end{array}$ & as heretofore & and heretofore & H9 O3 B24 1633 \\
\hline 16.ii.b & & & or as before & B47 \\
\hline
\end{tabular}




\begin{tabular}{|c|c|c|c|c|}
\hline 16.iii & & - full line - & $\begin{array}{l}\text { Shall own my soul and } \\
\text { cloth it evermore }\end{array}$ & HH6 \\
\hline 17.a & $\begin{array}{l}\text { B29 B46 H6 C10 H5 } 1633 \\
\text { H4 DT1 B7 CT1 }\end{array}$ & $\begin{array}{l}\text { And having } \\
\text { done that }\end{array}$ & $\begin{array}{l}\text { And having done this } \\
\text { then }\end{array}$ & H9 \\
\hline 17.b & & & And having this done & HH6 \\
\hline 17.c & & & And having done & B24 \\
\hline 17.d & & & $\begin{array}{l}\text { When this is done } \\
\text { then }\end{array}$ & O3 B47 \\
\hline 18.a & $\begin{array}{l}\text { B29 B46 H6 C10 H5 H9 H4 } \\
\text { DT1 B7 CT1 }\end{array}$ & I have & I ask & 03 \\
\hline 18.b & & & I'll ask & B47 \\
\hline 18.c & & & I need & B24 \\
\hline 18.d & & & I fear & HH6 1633 \\
\hline st. II-III & $\begin{array}{l}\text { B29 B46 H6 C10 H5 H9 O3 } \\
\text { B47 B24 HH6 } 1633 \text { H4 DT1 }\end{array}$ & II-III & III-II & B7 CT1 \\
\hline subscr.a & B29 B46 H4 DT1 & finis & finis D Donn & O3 \\
\hline subscr.b & & & $\mathrm{J}: \mathrm{D}:$ & B47 \\
\hline subscr.c & & & om. & $\begin{array}{l}\text { H6 C10 H5 H9 HH6 } \\
1633 \text { B7 CT1 }\end{array}$ \\
\hline subscr.d & & & John Hilton & B24 \\
\hline
\end{tabular}

The analysis of this variance is given in Table 4, below. In representing the phenomenon of textual flux in a tabular fashion, I have maintained (in the far-left column) the numeration of the stages from Table 2; accompanied by the listing of the archetype, here termed $x$ (as the first letter of the original title, Christo), followed by each subarchetype $(\alpha-\lambda)$; in the next column (justification) are the references to those variants which justify that archetype's existence. The fourth column, witnesses, lists those manuscripts which share the specific variant. These are prefaced by $>^{n}$, where $n$ indicates the number of sub-archetypes, or levels of distance, from the archetypal text. Underneath this listing of manuscripts, aligned to the right, are any witnesses which depend upon the aforementioned sub-archetype, and in the final column, further development, any other variants which are solely characteristic of these manuscripts (that is, idiosyncratic or terminal variants, which do not continue down the stemma by a process of direct transmission). The symbol " " indicates that a variant has given rise to a further variant reading; " ? " indicates that such a process is a probable explanation for the presence of differing variants. An italicized reference to a variant indicates its non-conformity to the overall picture of transmission. Both 
supplementary variation and unexpected variants are discussed in the clarificatory notes appended to Table 4.

Table 4 : Stages of Transmission

\begin{tabular}{|c|c|c|c|c|}
\hline & justification & witness & further development & \\
\hline & $\chi$ & archetype & & \\
\hline & $\{\alpha$ & $\begin{array}{l}\text { subscr.a } \\
\text { (subscr.c) }\end{array}$ & $\begin{array}{l}>^{0} \mathrm{~B} 29 \mathrm{~B} 46 \\
>^{0}(\mathrm{H} 6 \mathrm{C} 10)\end{array}$ & \} \\
\hline 01 & $\beta$ & title.a(b-d) & $\begin{array}{l}>^{1} \text { H5 H9 O3 H4 DT1 B7 } \\
\text { CT1 }\end{array}$ & (om. B24 B47 var. HH6, 1633) \\
\hline & & & > H5 & subscr.c \\
\hline & $\gamma$ & 5.ii & $\begin{array}{l}>^{2} \text { H9 O3 B47 B24 HH6 } \\
1633 \text { H4 DT1 B7 CT1 }\end{array}$ & \\
\hline & $\delta$ & $\begin{array}{l}, 13 . i, 17 . a / d \\
\text { (1.a/c, 14.ii.a-b, } \\
\text { 16.ii.a-b) }\end{array}$ & $>^{3} \mathrm{H} 9 \mathrm{O} 3 \mathrm{~B} 47$ & 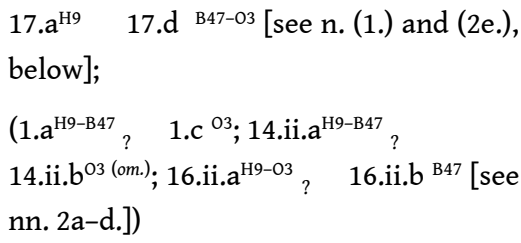 \\
\hline & & & > $\mathrm{H} 9$ & 8.b, 15.ii.b, subscr.c \\
\hline & $\varepsilon$ & $\begin{array}{l}\text { 5.i, 11.i, 13.ii, } \\
\text { 17.d, 18.ab }\end{array}$ & $>^{4} \mathrm{O} 3 \mathrm{~B} 47$ & \\
\hline & & & $>03$ & $\begin{array}{l}\text { 1.c, 7.i.b, 8.a, 9.b, 14.i, 14.ii.b, 14.iii, 15.ii.a } \\
\text { [see below, n. (5.)], subscr.a }\end{array}$ \\
\hline & & & $>\mathrm{B} 47$ & title.b, 3.a, 4.b, 7.i.a, 9.a, 16.i.b, subscr.b \\
\hline & $\zeta$ & 2.ii & $\begin{array}{l}>^{3} \text { B24 HH6 } 1633 \text { H4 } \\
\text { DT1 B7 CT1 }\end{array}$ & \\
\hline & & & $>$ B 24 & $\begin{array}{l}\text { 1.b, 16.i.a [see n. (3.) below], 16.ii.a [see n. } \\
\text { (2c.)], 18.c, subscr.d }\end{array}$ \\
\hline & $\eta$ & 7.ii & $\begin{array}{l}>^{4} \text { HH6 } 1633 \text { H4 DT1 } \\
\text { B7 CT1 }\end{array}$ & \\
\hline & $\theta$ & $\begin{array}{l}\text { 7.i.c-d, 18.d, } \\
\text { subscr.c }\end{array}$ & $>^{5} \mathrm{HH} 61633$ & \\
\hline & & & $>\mathrm{HH} 6$ & Tit.c \\
\hline
\end{tabular}




\begin{tabular}{|l|l|l|l|l|}
\hline & & & $>1633$ & $\begin{array}{l}\text { Tit.d, 2.i [see below. n. (4.)], 3.b, 4.a, 15.i, } \\
\text { 16.i.a [see n. (3.)], 16.ii.a [see n. (2c.)] }\end{array}$ \\
\hline 02 & $\kappa$ & $15 . \mathrm{ii.a}$ & $>5$ H4 DT1 B7 CT1 & \\
\hline 03 & $\lambda$ & $\begin{array}{l}11 . \mathrm{ii}, \quad \text { II-III, } \\
\text { subscr.c }\end{array}$ & $>$ B B7 CT1 & (subscr.a) \\
\hline
\end{tabular}

\section{Clarificatory notes.}

(1.) 17. $\mathrm{a}^{\mathrm{H} 9}$ "and having done this then" $17 . \mathrm{d}^{\mathrm{B} 47-03}$ "When this is done then". The initial $\delta$ - change in $\delta$ but recorded only by $\mathrm{H} 9$ (this then for that, perhaps mistaking the latter word for $\varepsilon \quad$ abbreviated forms of the two words) created an unmetrical line, which was solved in subarchetype $\varepsilon$ by changing the initial words rather than suppressing the addition.

(2.) The following three variants do not affect the readings that the sub-archetypes would have offered (they do not change), but one manuscript, either 03 or B47 produce a variant built upon the previous:

(2a.) 1. $\mathrm{a}^{\mathrm{H} 9-\mathrm{B} 47}$ "the $\operatorname{sin"}, \quad$ 1.c ${ }^{03}$ "those sins" (archetypal reading: that sin); the temptation to make the sin plural was also felt by B24 ("the sins"), but there is no real reason to suspect contamination.

(2b.) 14.ii.a ${ }^{\mathrm{H9-B} 47}$ "I should perish" ? 14.ii.b ${ }^{03}$ "I perish" (i.e. om. auxiliary verb; archetypal reading, I shall perish). The best one can say about the omission is that it does not contradict the readings one would expect according to the stemma; and so 03 certainly omitted should rather than shall.

(2c.) 16.ii.a ${ }^{\mathrm{H9}-03}$ "and heretofore" ? 16.ii.b ${ }^{\mathrm{B} 47}$ "or as before"; the sub-archetypal reading was most probably and heretofore, a slight misreading of the archetypal as heretofore. The variant was probably caused by the misreading of as as an ampersand (\&), which is a relatively easy mistake to make owing to the ligatures and the slightly bowed shape often given to the long-s (s): a similar misreading affected both B24 and 1633 at this point.

(2d.) At 8.a, B47 produces the archetypal reading, "made my sin their door", which contrasts with "made their sin my door" of 03. H9 would seem to support 03's version, with the scribe writing originally "their sin my door" (om. made), with a similar transposition of possessive pronouns as that found in 03. However, the $\mathrm{H} 9$ scribe realised that a mistake had been made, and returned to the line to offer a superscript correction: "their sin was my door". This is not as easy to disentangle as other variants, although the garbled, and then further garbled, version of the line in $\mathrm{H} 9$ would suggest that sub-archetype $\delta$ itself bore a confused or confusing reading at this point, which the scribe of $\mathrm{H} 9$ was attempting to elucidate; this confusion in $\delta$ was passed on to sub-archetype $\varepsilon$, where again the scribes attempted some remedy: B47 guessed correctly; $\mathrm{O} 3 \mathrm{did}$ not. ("(In)correctly" only if the scribe's purpose was to reproduce the previous manuscript tradition; the "incorrect" reading may have been perfectly purposeful.) 
(2e.) H9 is a singleton, but B47 and 03 are both florilegia. Although the sub-archetypes - here, specifically, $\delta$ and $\varepsilon$ - are really best thought of as hypothetical constructs which act as nodes within the stemma, whose existence is merely pending the discovery of further witnesses which may cause them to be further multiplied, and so redefined, or removed, it is very likely that the transmission of these texts passed through other anthologies rather than any collected works of the poet himself. Thus we may point to the likelihood of a common source for B47 and 03 texts in another, earlier florilegium since both exemplars of our poem are found in close vicinity to the Thomas Carew poem, A flye that flew into my Mistris her eye, although they bear different titles (03: "The Amorouse Fly", p. 9; B47: “An Epitaph vppon a Fly", fol. 221r-v); that titular variation, though, might signify nothing more than that the model bore no title for this particular poem.

(3.) A particular challenge to the stemmatic dependence of witnesses in this section of the apparatus is provided by the variant common to 1633 and B24 at 16.i.a, where the sun is referred to as "he" (against the unanimous third-person neuter pronoun throughout the rest of the manuscript tradition). There may well be strong theological reasons for the change, which were felt by both scribes; alternatively, a reminiscence of Hilton's setting (which may have been tolerably popular) affected the copyist or printer in setting down the text.

(4.) 2.i: archetypal reading: is my sin; variant reading: was my sin; the variant reading here is shared between $\mathrm{H} 9, \mathrm{O} 3$ (but not B47) and 1633. Such variation probably reflects a situation in which the sub-archetype originally offered both possibilities, one tense of the verb written as a - variant of the other-such as indeed has been preserved in B46, which adopts the reading was - in the text, yet provides the variant "is" in the scribe's own hand at the left margin. We may draw a parallel with the subscription, "finis", which was also maintained by B46 and passed down the chains of transmission to H4 and DT1, and, in modified form, to 03. Thus we probably have the remnants of scribal annotations preserved through sub-archetypes but only occasionally surfacing in the texts that are preserved.

(5.) The common variant between 03 and H4 DT1 B7 CT1 at 15.ii.a, this sun is surely an example of polygenesis. 03 originally read "thys", which probably indicates that its model still read the archetypal "thy", and that the scribe was misled by a ligature or flourish to the $-y$. H9, which descends from the sub-archetype above 03's own sub-archetype, offers "the" (15.ii.b), which suggests that, in this side of the transmission, the reading was uncertain or indistinct, possibly giving rise to two possibilities in the same text. I suggest below that the change may have been attractive as a reaction to an allegorical reading of "sun" as "Son", Second Person of the Trinity; both this and the make the reference resolutely this-worldly and so maintain the addressee as Christ.

Figure 1: A Stemma. 


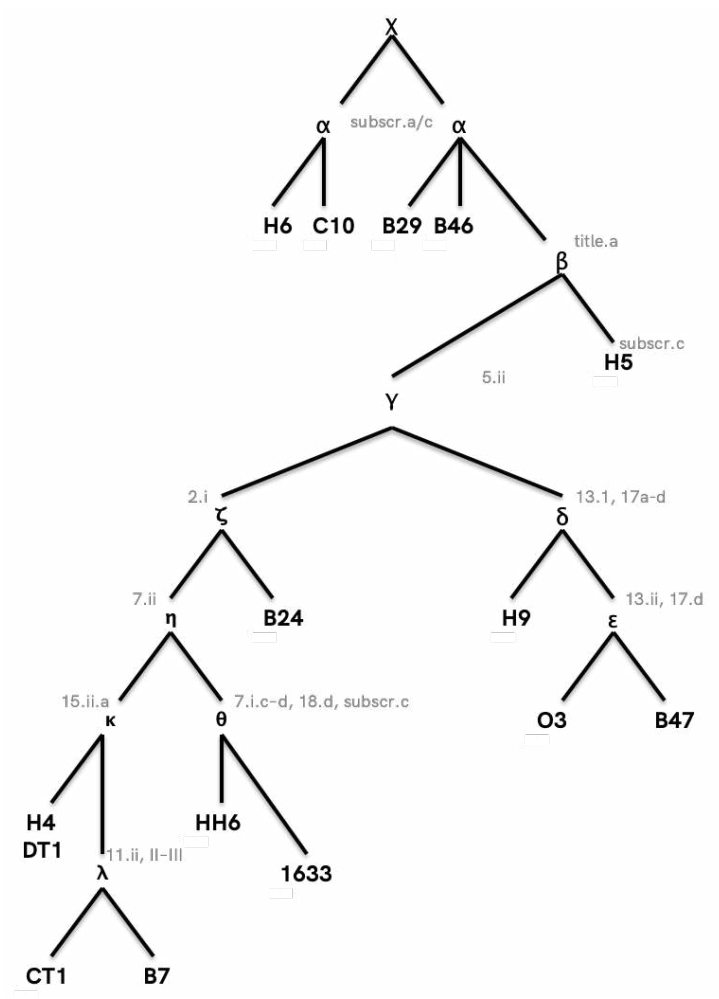

The pattern established, of successive changes at different stages of copying, evidently argues against any authorial revision producing a "new version" of the poem, and argues for a branching out of scribal innovations and emendation. Significantly differing versions, taken out of the context of the flow of the manuscript tradition, might well seem to provide a significant leap which would justify the assumption of a coherent, single authorial or scribal intervention to create a second recension, which is essentially what Pebworth produced through his classifications of Texts 1,2 and 3, and his corresponding exclusion of significant variants. Robbins, in his election of DT1, could hardly have chosen a text further away from the archetype. In contast to the vast majority of manuscript traditions, where copying only brings about textual decay, incoherence, loss, deturpation, metrical irregularity and, eventually, irremedial chaos, the copying of these short poems saw active, engaged, intrusive copying on the part of the scribes with a sensitivity to metrical and other forms of seeming errors, and a consequent preparedness to correct and emend the texts that they were then themselves partly writing. Robbins' principle, that of looking for the best text, or the one with fewest obvious errors, was not necessarily a bad one, particularly if one intends to comment upon all of Donne's poetry and not just dissect less than twenty lines of it; but the principle can be very misleading in a textual tradition where copying is not done by drudges, but by connoisseurs of the poetry itself. As we can see, the attentive, even playful, copying that transmitted this poem did not necessarily produce a degraded text - far from it; the alteration of the sequence of repetitions found in 03 , for example, produces a different, but no less effective, set of emphases.

There is now little need to wonder about the earliest state of the text: four or five witnesses give us a coherent and consistent version; there are no indications that there is any subsequent interference by Donne in the manuscript transmission. At most one might argue about the mis-en-page and punctuation of the archetype; but the sequence of words is not in doubt. This confirms Pebworth's conclusion regarding the authority 
of the Christo salvatori-version of the poem, and it is this - and only this - which should be accepted as Donne's own work. If the purpose of the article had been to identify those texts which most closely reflected the archetype, and establish Donne's handiwork, purified from the additions of others, then it might stop here, or proceed to analyse only the archetypal version, that is the Christo salvatori-version. Yet this was not the purpose; in a manner similar to my recent analysis of Valediction: forbidding mourning (Lappin 2019), I propose to study the variance of the poem as a function of scribal presentation and development, in order to provide a global understanding of the text as it was both written and transmitted; this article reinforces the conclusions of its twin.

\section{Reading and Writing the Poem}

Robbins, noting the similarity in themes to both sermons and poetry which Donne preached and wrote around the time, places the composition of the poem shortly after Anne More's death (Robbins 2013, 654), and there can be little reasonable disagreement with such an estimation. In further support of this, we might observe that the connexion with his wife's demise is particularly strong in a 1620s miscellany volume of poetical works in both English and Latin, B29 (London, British Library, Harleian ms. 3910), where the poem (in the Christo salvatori-recension) precedes Donne's own Latin epitaph for Anne More (foll. 50r, 51r), the two works separated only by Richard Cobbet's ironic epigram on Lady Arbella Stuart's burial in 1615 ("Vpon the Lady Arabella" at fol. 50v; see ).

\section{The title}

The original text of the poem, then, offers us a view of the poet tormented by grief, and addressing a prayer to Christ, the Saviour, Christo Salvatori. And although ideas of the salvific power of Christ might be expected to give origin to emotions of tender devotion and gratitude, invocation of Christ the Saviour was done with at-times theatrical angst, for it was Christ the Saviour who was to appear also as, at the same moment on the Last Day, Christ the Judge. ${ }^{3}$

Thus the first line, "Wilt thou forgive [...]" suggests immediately the two aspects of Christ, as saviour and judge: saviour should he offer forgiveness; judge if he withholds it. The vernacular simplification of the title, then, in removing the concept of the Salvator from the beginning of the poem subtly shifts the emphasis from a concern with the Last Day to a general prayer to Christ. The change may simply have been motivated by a shift in audience, away from the bilinguals of his inner circle for whom Donne generally wrote, to a more resolutely native, and possibly naïve, readership, for whom it might have been desirable to remove (together with the Latin) a possibly unwelcome Catholic insistence upon the importance and unwelcome uncertainty of that particular dies illa.

\section{Stanza One}

The poem begins very much at the beginning, however, since the first request for, or questioning about, forgiveness regards Original Sin, the sin passed down as damnable 
inheritance from generation to generation, from Adam to John: as Psalm 51:5 memorably expressed the fault, "Behold, I was shapen in iniquity; and in sin did my mother conceive me." Such an orthodox interpretation is commended in at least one manuscript, $\mathrm{CH} 1:^{5}$ a marginal annotation adds "Originall" level with these initial verses.

The most important variant in these lines is undoubtedly the verbal tense at 2.i: is vs. was. The difference between these tenses is not minor. Was places the Original Sin as being a sin from and belonging to the past, and invokes the more Catholic and Lutheran understanding of the sacrament as "washing away" Original Sin: after baptism (and Donne had, after all, been baptised a Catholic) that Sin could no longer be his. The present tense, is, however, suggests a much more Calvinist understanding of the role of baptism. This was not an outward sign of inward grace, but a promise of forgiveness, to be brought to mind when the faithful yet still regrettably sinful believers had made themselves anxious over the possibility of redemption: working oneself up over the certainty of one's own salvation (or, rather, of its opposite), only to then assuage the tormented mind by a recollection of the divine promise, is a characteristic element of Calvinist mental theatre. "Is" must be the primary reading; "was" introduced at first as a scribal quibble, rather than as a simple replacement, a quibble brought about by a divergent theological sensibility.

Thus, in a contemporary summation of received opinion - offered by Samuel Ward, master of Sydney Sussex College, Cambridge, during the 1620s - baptism was only "conditional and expectative, of which they have no benefit till they believe and repent". Donne's problem, which he will explore throughout the poem, is what happens if one only sort-of believes, and only sort-of repents? And the cause for his halfhearted, or insufficient, repentance may allow us to place Calvinist theology temporarily in the background, and bring the poet's biography to the fore: the sin "where I begun" recalls the same phrase with which he ended his Valediction: forbidding mourning, which, even in Izaac Walton's highly sentimentalist reading of the same, was dedicated to Ann More to commemorate one or other parting (Walton 1675, 33-34): 6 here the echo emphasizes that definitive parting of the grave, and the recollection of "where I begun", the triumphant return of the poet to the beloved in Valediction, is applied to the sin, his over-attachment to his wife, perhaps, his inability to abandon his love and grief for her, his excessive delight in the physicality of their relationship, or even the guilt he felt for having seduced her in the first place. ${ }^{7}$ She had died in childbirth, after all, and Donne, despite his many faults, was not an irresponsible sadist. This emphasis on the human, biographical experience of the poet - rather than the theological inheritance from Adam - was emphasized through the shift in two unrelated witnesses to a plurality of sins in the first line (1.b-c: B24, O3), perhaps in part to avoid the doctrinal question of Calvinist sacramentalism.

The second half of the second line picks up this biographical focus, "though it was done before", with the first inkling of the multiple senses of done / Donne, as contemporary orthography did not consistently distinguish the words: ${ }^{8}$ on the one hand, the sin was in the past, done before the now of the poem, committed even before the existence of the poet. On the other, the sin itself continues to be his, even though it was much more characteristic of Donne in his youth; and the nominatively deterministic done was of course slang, referencing the sexual act. ${ }^{9}$ Although he might have put his youthful enjoyments behind him, they dogged him, even through his name. Robbins adroitly cited an excerpt of one of Donne's sermons composed four months after his wife's 
death: "We may lose him [Christ], by suffering our thoughts to look back with pleasure upon the sins which we have committed" (Robbins 2013, 90; citing Sermon 1.245 on Proverbs 8:17). The shift to the subjunctive mood, "though it were done before" (2.i: one of the earliest emendations to the poem in transmission), closes off the concrete, biographical reference, to leave only hypothetical possibility or evocation of the distant, pre- and immediately post-lapsarian past.

The parallel senses, of theology and biography, are brought together in the following lines as the poets' current state is evoked: in the archetypal text, this is marked by a shift from the previously singular sin to plural sins, and their shifting multiplicity ("through which I run"), serious not simply in number but also in their commission ("and do them still"). Just as a polyptoton is performed by is reappearing as was in ll. 12, so done (1. 2) returns as do (1. 4): the sins of the past may no longer characterize him, but that does not mean that he is free of sins. The alteration of "do them" to "do run" in 1633 (4.a) allows the pious reader to imagine the late dean of St Paul's not so much committing sins, but ineffectually fleeing from them, trapped as he cannot but be by the surrounding world, a world, despite his best efforts from the pulpit, of sin. With Original Sin (or Donne's original sins) added to his present sins - sins unnamed and elusive of identification - one passes to the final verses of the stanza: as the archetypal text has them, "When thou hast done, I have not done / For I have more". Christ is addressed as "doing" the forgiveness, but in vain, since Donne himself has more sins. The evident allusion to Anne More's name has only relatively lately been accepted by readers of the poem (Leigh $(1978,90)$; queried by Novarr $(1987,291-92)$; reaffirmed by Ahl $(1988,22)$ ), no doubt because of the excessive crudity of the paronomasiae: have, like do, possesses a raw sexual undertone,$^{10}$ which - once accepted - flows back into the thou hast of the previous line, providing a shocking juxtaposition to Christ, presenting Christ's forgiveness as a form of sexual possession. Such a conception, though, of himself vis-à-vis the divinity was in fact a fixed element of Donne's own spiritual self-presentation (Challis 2016). And, although it may present a transgressive air within the confines of an expected or normative Protestant religious discourse, it can hardly have been unfamiliar or outlandish to anyone even slightly acquainted with Spanish religious poetry, and Donne's acquaintance with the poetry of the Spains was hardly slight (see Grierson (1912, II.4); Thompson (1921); Cora (1996); for the tradition of meditation: Roston (2005)).

Nevertheless, the archetypal rendition of the line ("When thou hast done, I have not done") is not followed by most later witnesses (5.ii): "When thou has done, thou hast not done". Since this variant line simply repeats what is found in the second stanza in the same place in the archetypal text (1.11), it is most likely that this variation was initially the product of eyeskip. ${ }^{11}$ As a principle, mechanical error is usually a better explanation than purposeful emendation, and so I will assume that this change is a simple error, unmotivated by any intention. Nevertheless, the manuscript in which it occurred provided a bottleneck, and subsequent copies of Donne's poem flowed from that exemplar.

31 Yet that is not the only variant at this point. 03 and B47 both provide a confirmation that the allusion to the poet's own name was an important element for some readers (5.i): "When this is donn, thou hast not donn". This does not aid in the extrication of a single meaning, since it generates a number of referents: the word might invoke God's forgiveness $(11.1,3)$ which has been granted; or might - relying upon the second half of 
1. 2 ("though ytt was donn before") - point to the completion of his running through sins, his abandonment of his sinful ways; or, in complete contradiction of this second meaning, point directly at the poet himself, and so the phrase would mean "Whilst Donne behaves in a way characteristic to himself, that is sinfully". All these meanings flow seamlessly into the second half of the line: "thou hast not done" (finished forgiving, gaining Donne to Himself), with the humorous reversion of roles: Christ is not done, cannot leave off forgiving, precisely because Donne is Donne.

\section{Stanza Two} acts (l. 3), exacerbated by the consciousness of their sinfulness (1. 4), to subsequently refer to a characteristic disposition, a type of behaviour (1. 7); and then, in the present stanza, to epitomize "sinfulness", the sinful life, for which he provided the "door" for others to enter into (1. 8): the orthography of, for example, H6, makes clear that, in the phrase "won / others to Sinne", $\sin$ is understood as a noun rather than a verb (see Pebworth 1987, 20), and door has perhaps a biblical sense of an anti-type to the narrow gate which leads to eternal life (Matthew 7:14). The field of reference is completed by sin which is conceived not as a momentary lapse, but as a repeated surrender to a specific temptation (1. 10), in full consciousness of its sinfulness (1l. 9-10, cp. 1. 4, "deplore"). All-in-all, an impressive display of traductio or antanaclasis using the various meanings of "sin".

these sets of foci, then, we might say that Donne is fulfilling relatively precisely Calvin's own instruction to the pious (Institutes III.20.9) on how they should conduct their prayers:

Finally the beginning and also the preparing of praieng rightly, is crauing of pardon, with an humble and plaine confession of fault. [...] For Dauid when he asketh an other thing, saith: Remembre not they sinnes of my youthe, remember me according to thy mercie for thy goodnesses sake 0 lord. [...] Where we also see that it is not enough, if we euery seuerall day do call our selues accompt for our new sinnes, if we do not also remembre those sinnes which might seeme to haue been long agoe forgotten. For, the same Prophet in an other place, hauing confessed one haynous offense by this occasion returneth euen to his mothers wombe wherin he had gathered the infection: not to make the faulte seme lesse by the corruption of nature, but the heaping together the sinnes of his whole life, how much more rigorous he ys in condemning himself, so much more easy he maye finde God to entreate. 
(Calvin 1561, 207v) enumerates the sins of his conception and his youth. The reason for doing this was to make God more likely to grant his prayers, which were for forgiveness; however, if forgiveness is to be gained by individual confession to God, and God is more likely to forgive in proportion to the number of sins dredged up from the past, then asserting that one has more sins to confess makes it more likely they will be forgiven - ad infinitum. This is the theological (and rhetorical) conundrum which Donne is exploring in the penultimate and ultimate lines of each stanza. In this second stanza, however, the Christo salvatori-text provides a variatio to the penultimate line: 1l. 5-6 offered "When thou hast done, I have not done / For I have more"; 11. 10-11 inflects to "When thou has done, thou hast not done / For I have more". The expectation would be that Christ has not finished forgiving: Donne will confess more sins, which he does. But no longer is it Donne who has not finished sinning (and so needs to list more sins), rather the sin he will confess is of another order. And so Christ here will neither finish forgiving (perhaps He has not even started), nor will He gain Donne to himself, since Donne has something else up his sleeve.

\section{Stanza Three}

What Donne does not do in the first line of this stanza is ask whether he can be forgiven for the sin he will confess to in the third stanza. He breaks the expected rhythm he had established with the anaphoric "Wilt thou forgive [...]" that begin the first two stanzas. Indeed, Christ has not done, has not finished His activity, since He is being asked something quite beyond ordinary forgiveness, which in effect contradicts the possibility of ordinary forgiveness. What is being requested - if not demanded - is a personal promise to the poet that he will be numbered amongst the elect. For the Calvinist, there would be a quota even for salvation; those who would be counted amongst that number were already predestined to eternal bliss; therefore, no amount of confession of sins could change the brutal fact of divine election (or divine damnation). As Oliver observed regarding our poem:

The Calvinist doctrine of the limited atonement directly challenged the individual to believe that he or she was among those for whom Christ had died. Hence the speaker's elaborate and ingenious plan to be sure that he is one of those benefited by Christ's death. The logical objection to this is that, if he is among the elect, the merits of Christ's death will already have been "applied" in his case. No amount of wishing for a personal manifestation of their application will make any difference to the divine arrangements: Christ cannot be crucified afresh, except in the imagination. What's more, the elect know that grace is working in them-that the merits of Christ's death have been applied in their cases.

(Oliver 1997, 90)

Oliver goes on to observe that "The speaker's prayer thus amounts to an entirely selfdefeating request to be counted among the elect", although I feel that Donne's bargaining with the divine may be slightly more complex, even slightly more cunning. From a theological point of view, Donne confesses another sin, but one of a different order to the previous enumeration, a theological sin, as it were, one of fear or doubt that he will be saved; essentially, a lack of faith; and, within the Protestant soteriology he had embraced, it was faith alone which justified; without faith, there could be no salvation; the one Really Bad Thing a believer could do, that which would utterly derail 
their salvation, was doubt that they could be saved. And that is precisely what Donne insists on confessing. Christ cannot forgive a lack of belief, since the forgiveness of sins offered by Christ is predicated upon the individual's believing in that forgiveness (which He gained for mankind through His single sacrifice upon the Cross). It was pointless getting angsty over whether you were going to be one of the lucky few crammed into that ultimate elevator, if you really were unsure you could actually keep your balance on the narrow tapis roulant of faith which would take you close to those sliding, pearly doors.

This "sin of fear" is not unrelated to his previous evocation of Original Sin; indeed, it was already there in semine. As we have noted, for Calvin, recollection of Original Sin was inseparable from baptism, and the recollection of baptism re-assured the baptised that their sins would be forgiven (although they had not been forgiven through the ritual); forgiveness and salvation were thus postponed to the moment of death and Judgement. Baptism (for the baptised) was thus designed to provide a reassurance (in the imagination) of future salvation. Calvin had opined (Institutes VI.15.9):

In the Cloude was a signe of cleansyng. For as then the Lorde couered them with a cloude cast ouer them, and gaue them refreshing colde, least they should faint and pine away with to cruell burning of the sunne: so in Baptisme we acknowlege our selues couered and defended with the blood of Christ, least the seueritie of God, which is in dede an intollerable flame, shoulde lie vpon vs.

(Calvin 1561, 102r)

A christening carried out by recusant Catholics may have had rather less of a consolatory impact upon Donne's imagination than had he been assured that he had received his baptism surrounded by the righteous elders of the true church.

Donne's description of his feared death picks up both Calvinist anxieties: of predestination, and of consequent futility: "when I have spun / my last thread, I shall perish on the shore" (1l. 13-14). The allusion would seem to be to the silkworm, whose cultivation in London had been encouraged by James I and VI after 1607, and had become a long-term success (Peck 2005, 91): after the completion of its cocoon (its last thread), the caterpillar was killed to gain the silk (shore: river-side sewer, where it would be cast; cp. Williams (1994, 387), s.v. "common shore"). The grub would die without fulfilling its (biological) destiny of gaining wings; the poet would die without transformation to "become like the angels", the spiritual destiny of redeemed humanity. However, whatever the possible telos of each being, neither was predestined for flight: the cultivated silkworm destined to die as soon as it had begun its process of transformation; the disbelieving poet, (pre)destined to damnation even as he died acknowledging his sins (particularly his sinful lack of belief), his soul perishing on one side without ever reaching the "ripa ulterior", the farthest and last shore. ${ }^{12}$

The solution to this impasse is to seek a solution from the Old Testament: a personal covenant with God: Christ is instructed (via a rather daring imperative) to guarantee, swearing by God, that is, by Himself (1. 15), to guarantee the poet's salvation. Covenantal theology (reliance upon God's having bound Himself via an oath or promise) had become an increasingly popular means of expressing God's relation to the chosen people (that is, themselves) amongst proto-Puritans (Holifield 1974; Von Rohr 2002), and it was probably from this environment that Donne took his inspiration. Obviously, with Donne, the "covenant" could not be just with the people of God to be satisfactory, but must focus on Dr John Donne - but, to be fair, it must focus on Dr John Donne, not because he was especially worthy, but because he was honest enough to face 
up to how he himself fell through the cracks of the Calvinist-Puritan theology of redemption.

Given the later development of the poem into print, where the poem is addressed to God the Father and the Son that shines is evidently Christ, it is not surprising that "thy sunne" has been elided with Christus Oriens, Christ the Rising Sun, by commentators (Pebworth (1987, 22-23); Robbins (2013)). It was perhaps to prevent such a leap that, at 15.ii.a, the reading changed to "this sunne" at $\kappa$, to make clear that an allegorical reading was not being sought. Nor, I think, was allegory the aim in the archetypal text: "thy sun"; so not Christ as the sun, but Christ as owner of the sun; the Christ through whom all things were created - the Christus creator - together with the Christ through whom all things are saved - the Christus salvator - (see, inter alia, Colossians 1:12-20). Thy sun, then, undoubtedly just originally meant the sun (which is the sensible conclusion of the scribe of H9: 15.ii.b). Donne asks Christ to keep the sun shining, just as the sun has shone up to the present. The biblical comparator is, in part, Genesis 22:16 ("And said, By myself have I sworn, saith the LORD, for because thou hast done this thing, and hast not withheld thy son, thine only son"), ${ }^{13}$ and, more importantly, the commentary on the same provided by St Paul at Hebrews 6:13, "For when God made promise to Abraham, because he could swear by no greater, he sware by himself". Within such a context, the printer's decision to make the addressee God the Father is particularly understandable.

Yet the promise Donne would see enacted was but a daily phenomenon. How - given his "sin of fear" - was he to know that Christ had sworn anything? Personal assurance was requested: but what certainty could possibly be received? The final lines, in our archetypal recension, do nothing to dispel this clouded vision of salvation: "And having done that, thou hast done / I have no more". The traductio of the final lines to each stanza have been poised between present and future: current forgiveness of sins (or current potential forgiveness of sins), and future definitive forgiveness of sins. The play on the poet's name (and Anne's) remain, but the temporal situation is unclear: does the poet simply assume that Christ has now sworn to save him, or does he defer this resolution to the future, a future when Christ will clearly promise, or a future when Donne will die - at that point, indeed, Donne will cease to have his earthly and sinful attachments: no more. The irony - surely not lost on Donne in evoking himself as a silkwork - was that, in contemporary sericulture, the worm was killed whilst still in the chyrisalis by exposure to the sun (Bonoeil $(1622,28)$; further, Staples and Shaw $(2013$, 159-61); Hatch (1957)).

The variant to the final line provided by the 03 and B47 manuscripts (18.a-b, "ask" for have) preserves the bathetic suspension; the poem ends as a prayer; B47, by using a future tense (I'll ask) also makes clear within its own structuring of the poem that the resolution is cast towards the poet's death. Hilton's variant, need (18.c), works in a similar fashion. ${ }^{14}$

It is, however, with the intromission of feare (18.d) as a variant to the last line that the ending is significantly changed, and this alteration cannot be seen outside the shift in the addressee of the poem: God (the Father) rather than Christ; the latter is now the Son who shall save him at the last, and this recollection (as it should for a devout believer) will cast aside the fear that formed the final, seemingly unreconcilable, sin. This theological emphasis is taken even further in HH6, where the Son does not simply shine down grace upon the dying Donne but will "owne my soule and cloath itt 
evermore": owne absorbing and neutralizing the various verbal plays on have; cloath draping the heavenly garment of salvation over the thin and final thread of the poet's existence (for the "garments of salvation", see Isaiah 61:10 and Matthew 22:11).

In the hands of these copyists, the poem is thus de-Donnified, turned much more specifically into a "hymne" (as in the title given in the princeps), a devotional song to the first Person of the Trinity. Its underlying intention is to praise the Most High, with the address to God cast within a recognizable theological framework. The structure of the poem thus enacts a crisis, resolved into assurance by a theological reflexion; it evokes anxiety, only to dispel it, and can take the reader (or, indeed, singer) through an imaginary process of repentance, doubt and resolution; the very lack of specificity of the sin or sins mentioned allows the reader-partaker to apply them to her own biography, evoking a personal sense of sinfulness which may be assuaged by a reaffirmed belief in forgiveness. Memory can be briefly reconfigured within a dominant theological paradigm, and emotions, similar to those assumed to have led to the composition of the piece, can be conjured within the reader. Within the hymn-genre, then, the I-function of the text is shared between author and performer-worshipper, or rather the process of enunciation is taken over by the devotee, using the author's words to express and suscitate devotion through a form of ventriloquism. That the transformation of Donne's own idiosyncratic poem into a genre-following Hymn was not a sudden rewriting, but an example of consistent normalizing pressure on the text exerted as scribes and printers altered it in their copying, shows how important ideological expectations can be in transmission, and how carefully modern editors must tread in discerning how texts may be transmitted and altered, even as they are copied into authoritative manuscript collections.

\section{The author and his image}

The evolution of our poem, too, doubtless reflects the on-going development of the "author-function" (Wilson (2004); for England, Armstrong (2007)) or "author-image" (Amossy 2009) of Dr Donne, famed divine and sermonizer; and displays how expectations from his output also developed in tandem with his increasing absorption into the English church's hierarchy. It is most certainly one thing to read a racy poem about love, sex, grief and doubtful forgiveness by a famed roué only recently of the cloth; quite another - indeed, somewhat difficult, perhaps repulsive - to read a racy poem about love, sex, grief and doubtful forgiveness by an aged and venerable divine, celebrated for his learning and his lack of public dalliance.

Yet what is also noticeable, however, is that, despite the canonization of his works in print, and the presentation of a sanitized version of "A Hymne [...]" as the culmination and end of Donne's poetry, some anthologists a few years later still preferred the rawer, less formally devout versions that are included in $\mathrm{H9}, \mathrm{O} 3$ and B47. I would not want to say that these were acts of resistance to a dominant characterization of Donne; but they do show an interest in Donne's rather more characteristic and less normative religiosity, perhaps a taste, even, for uncertainty, doubt and theological conundra.

Yet even with all the editorial development it underwent, the poem still had the potential to be somewhat disturbing. The copyist of CT1, whom we met earlier with his (or her) identification of the sin of the first lines as being "originall", placed two widely-known Latin sententiae warning against hypocrisy and duplicity in the space left 
at the bottom of the same page: "Amicis vitia si feras facis tuae" (if you bear your friends' vices, they become your own) and "Simulata sanctitas, duplex iniquitas" (holiness feigned, doubled iniquity). The first originally appeared in a classical assembly of maxims (Duff and Duff 1934, 4); the second was much used, and often attributed to Jerome, or Gregory, or Augustine. It is difficult not to suspect that these Latinate admonishments were criticisms aimed directly at that roué turned venerable divine.

51 Such visible discomfort with Donne's persona may explain the really quite extraordinary lengths to which Walton went in forging a picture of a devout, upstanding, protestant individual in his successive revisions to his Life of Donne. Our poem was included as an example of Donne's devout verse from the very first version of the Life (Walton 1640), and was the only poem that made its way into a popular abbreviation of Donne's biography (Winstanley 1687, 120). But the poem was introduced as, explicitly, a hymn written during a bout of serious illness (Walton (1640, fol. 84v); Anne More being long forgotten, and readers certainly diverted from seeing any puns on her name). Such a connexion proved attractive to devout readers, and a future archbishop of Canterbury copied out the poem into his commonplace book, prefacing the verses with "Dr Donne in his former sicknesse" (Oxford, Bodleian Library, ms. Tanner 466, foll. 4v-5r). Crucially, of course, Donne's doubting that he could be saved was washed away in the version that had made itself into print, and which Walton used; and Walton made doubly sure of this pious inflexion to the poem by adding, after the fallacious setting on a sick-bed, that Donne "wrote this heavenly Hymne, expressing the great joy he then had in the assurance of Gods mercy to him". The theological, biographical and spiritual problem, which gives the poem its force, is simply erased.

52 This was still not enough, and Walton, in a subsequent return to his biography, bolstered the account with some reported words of Donne "to a friend" (unnamed, of course) after listening to the setting of the hymn: "The words of this Hymne have restored to me the same thoughts of joy that possest my soule in my sicknesse when I composed it" (Walton $(1658,77)$; Walton $(1670,55)$; Walton was not one for varying an idea once he had seized upon it). Hilton's setting was thus co-opted to characterize Donne as having a sincere and heartfelt pious sensitivity. And to emphasise that the hymn was meant to express and awaken "joy".

There are thus wider and longer-lived issues at play in understanding the variance of a poem, issues that involve the evolution of Donne's verse over time. Evolution not at the hands of the author, but as it was wrenched from an individual context of a life as it was being lived, to be placed in either an implicit or explicit idealized biography, the image d'auteur not only mediating how texts were read, but directly provoking interference in the transmission of those texts themselves. Despite the valiant efforts of the Digital Donne project, this process has not been fully rolled back, and much modern criticism of John Donne has been built upon texts which do not reflect the real Donne, but rather an amenable construct created, in the main, post mortem. When it comes to seizing "Donne" (image d'auteur, fonction-auteur, man), we have most definitely not done. Finis. 


\section{BIBLIOGRAPHY}

Ahl, Frederick. 1988. “Ars Est Caelare Artem (Art in Puns and Anagrams Engraved).” In On Puns: The Foundation of Letters, edited by Jonathan Culler, 17-43. Blackwell.

Amossy, Ruth. 2009. “La Double Nature de L'image de L'auteur." Argumentation et Analyse Du Discours 3. https://doi.org/https://doi.org/10.4000/aad.662.

Arber, Edward. 1877. A Transcript of the Registers of the Company of Stationers of London, 1554-1640. London: Edward Arber.

Armstrong, Guyda. 2007. "Paratexts and Their Functions in Seventeenth-Century English 'Decamerons'." The Modern Language Review 102: 40-57.

Augustinus, Aurelius Hipponensis. n.d. "Sermones de Tempore.” Augustinus.it. http:// www.augustinus.it/latino/discorsi/index2.htm.

Austin, William. 1635. Devotionis Augustinianae Flamma, or, Certaine Devout, Godly, and Learned Meditations Written by the Excellently-Accomplisht Gentleman, William Austin, of Lincolnes-Inne, Esquire. London: John Legat; Ralph Mab.

Bonoeil, John. 1622. His Maiesties Gracious Letter to the Earle of South-Hampton, Treasurer, and to the Councell and Company of Virginia Heere Commanding the Present Setting Vp of Silke Works, .... Also a Treatise of the Art of Making Silke. London: Felix Kyngston.

Calvin, John. 1561. The Institution of the Christian Religion. Translated by Thomas Norton. London: Reinolde Wolf; Richarde Harrison.

\section{NOTES}

1. When citing manuscripts, I also provide the sigla used in the Donne Variorum project (1995-), provided in their "Sigla for Textual Sources".

2. The mis-en-page is taken from the majority of witnesses to "Text 1": B29, B46, H6. In contrast, C10 indents the second, fourth, and fifth lines, but maintains the greater indentation of the sixth. In the later manuscripts, it is even lines (i.e.: $2,4,8,10,14,16$ ), which are indented, with a greater indentation for 11. 6, 12, and 18, as they end each stanza.

3. For example, the angst-ridden 126 lines of the second of William Austin's meditations for Good Friday, also entitled "Christo salvatori" (Austin 1635, 117-22); St Augustine counselled fearing the Saviour since he will also be the Judge (Augustinus, n.d., CCXIII.6).

4. So the King James; thus the Douay-Rheims: "For behold I was conceived in iniquities; and in sins did my mother conceive me".

5. Chester, Chester City Record Office, CR63/2/692/219, fol. 200r.

6. Walton entitles the poem A Valediction, forbidding to Mourn. For discussion of this poem, see, for example, Smith (1983, 118); McColley (n.d., 97-98); Targoff (2008, 75-76). For the biographical inaccuracy of Walton's account, see Walton $(1807,41$ note $m)$.

7. See also Lappin (2019), where I argue that rather than understanding the poem as an expression of marital attachment (which is Walton's presentation of the same), it was written to insist to Anne that she should not give any cause for suspicion before their secret marriage. "Where I begun" is thus a phrase with a particular biographical charge, even with a weight of guilt upon it. 
8. 03, for example, uses donn as spelling for both done and Donne; H6 offers donne throughout, which was the scribe's usual spelling of the past participle; for example: Sappho to Philaenis (24: Sappho), 1. 52, p. 231; The Sunne Rising (36: SunRis), 1. 28, p. 260; The Triple Fool (40: Triple), 1. 12, p. 255; The Extasy (63: Ecst), 1l. 1, 25, p. 302; The Blossome (68: Blossom), 1. 26, p. 284; Epistles: To $M^{r} R$. W. (122: RWSlumb), 1. 23, p. 219; To Sr Henry Wooton at his going Ambassador to Venice (129: HWVenice), 1. 24, p. 221; To Mrs M. H. (133: MHPaper), 1. 33, p. 239; To the Countesse of Bedford (134: BedfReas), 1. 28, p. 205; idem (136: BedfHon), 1. 11, p. 191; [Vpon the death of] Mrs Boulstred (151: BoulNar), 1. 16, p. 169; no examples of done or donn were found.

9. For example, Titus Andronicus, IV.ii.75-76 where the accusation, "Thou hast undone our mother!" is met with the riposte: "Villain, I have done thy mother!"

10. For example, Quaife $(1979,53)$, records the following court deposition: "coming by a chamber door that stood ajar, they thrust him open and stepped into the chamber and there they saw Richard Templeton having Agnes Moore against the bed". (Agnes was probably no relation to Anne). Further, Patridge (1968, 119); OED, s.v. have, §14e.

11. It is difficult to be categorically sure, but the transposition across the first and second stanzas of "I have" and "thou hast" in sub-archetype $\delta$ may have preceded the adoption of "thou hast" for both lines; alternatively, "thou hast" was the original reading of the copy, subsequently corrected by "I have" at the wrong position, a correction adopted by $\delta$ but spurned by $\varepsilon$.

12. Virgil, Aeneid VI.313-16, "Stabant orantes primi transmittere cursum / tendebantque manus ripae ulterioris amore. / Navita sed tristis nunc hos nunc accipit illos, / ast alios longe submotos arcet harena" [They stood, begging to be brought on the journey first, holding out their hands for love of that final shore. The grave boatman yet takes on board now these, now those, while he drives off others far from the sands].

13. The same covenantal promise is recalled at Exodus 32:13, "Remember Abraham, Isaac, and Israel, thy servants, to whom thou swarest by thine own self, and saidst unto them, I will multiply your seed as the stars of heaven, and all this land that I have spoken of will I give unto your seed, and they shall inherit it for ever". Further Supreme Self-swearing is found at Isaiah 45:22, Jeremiah 22:5; and God's swearing by His own name, at Jeremiah 44:26.

14. Given the fixation with death in the final stanza, we may pose the question of whether the subscription "finis" (subscr.a) is an authorial or scribal boundary-marker (as suggested above) or is, in fact, an integral part of the poem.

\section{ABSTRACTS}

Donne's short religious poem, which begins "Wilt thou forgive..." has undergone numerous changes in its journey through the hands of copyists and into print. The establishment of a stemma and its analysis shows an early, theologically difficult and questioning poem which was progressively altered by different hands, a process which turned the short verses into a devout affirmation of faith, something quite contrary to Donne's initial conception of the poem.

INDEX

Keywords: poetry, stemmatology, Donne, scholarly editing 


\section{AUTHOR}

\section{ANTHONY LAPPIN}

Anthony Lappin was born 1968 in Liverpool, gained his doctorate at the University of Oxford, and has taught in universities in the UK, Ireland and latterly Sweden, where he currently lives. He has also published a long article on the transmission of Donne's Valediction: forbidding mourning in Studia Neophilologica (2020). 